\title{
Citizen's Participation: Between Continuity and Change in Nigeria
}

\section{Anthony Eniayejuni}

\section{Nusret Sinan Evcan}

International Relations Department, Cyprus International University, Lefkosa, Mersin 10, Turkey eanthony@ciu.edu.tr, sevcan@ciu.edu.tr

\section{Doi:10.5901/mjss.2015.v6n6s1p328}

\section{Abstract}

Despite Nigeria's uninterrupted democratic governance and transition of political power from one democratic government to another in the last fifteen years, there is a growing crisis of detachment of government and the people, lack of transparency, lack of accountability, lack of responsiveness to the needs of the masses and corruption in the country. In order to tackle these issues; citizens participation is needed at all levels of governance. Five different events that took place between 2010 and 2014 indicate that increase citizen's participation in governance is crucial in enhancing the process that help government set the appropriate priorities, transparency, and accountability.

Keywords: Citizens Participation; Representation; Public Policy; Governance

\section{Introduction}

Despite Nigeria's uninterrupted democratic rule in the last fifteen years, it political space is characterized by lack of transparency, lack of accountability, and corruption. In order to ensure proper accountability, transparency, and effective government policy, participation of the citizens at all levels of governance is indispensable in enhancing government policy that will meet the needs and desires of the populace. Citizen participation in governance is the attempt made by citizens to influence public policy. Citizen participation takes place when citizens are organized and work together through some form of organizations to influence the decision making process. Often times, citizens get themselves involves in decision-making process that directly relates to them. Citizen participation help in monitoring and evaluating government policy and in turns help in shaping policy decision. A well-informed citizen will watch carefully how the public office holders and representatives use their power on public policies and issues; and will express their own opinions and interests concerning it by either disseminating the information or drawing media attention, as well as holding the decision makers accountable. Citizen participation includes citizen's involvements and participation in electoral process, obligatory participation in governance and decision-making process. In a democratic system, citizens are able to optimize their political resources. They are able to join any group, associations of interest and able to choose their own representatives who can properly represent and protect their interest. Thereby, citizens can ascertain whether there is a close alignment with their representative; or there are clashes of interest. The level of citizen's participation in the decision-making process is essential ingredient of a democratic political system and vitally important to democratic consolidation in Nigeria. This study aimed at revealing the importance of citizen's participation in governance by evaluating five different events that occurred in Nigeria between 2010 and 2014. First, protest against President Yar'Adua's failure to transfer power to the vice-president Goodluck Jonathan before proceeding on medical treatment in Saudi Arabia. Second, citizen's response to the removal of subsidy from petroleum products by the federal government of Nigeria on $1^{\text {st }}$ of January 2012. Third, the public objection to the construction of a building for the President's wife in Abuja named "Mission House for African Ladies" allocated in the Federal Capital Territory budget. Fourth, the public outcry over judgment passed on the senior officers in the Police Pension Board who were involved in the illegal diversion of funds. Fifth, the involvement of former Minister of Aviation, Stella Oduah in 255 million naira BMW armoured car scandal tagged 'Oduahgate'. For the in-depth coverage of government policies, activities, eyewitness accounts on citizen's participation in political events and editorial analysis of news; selected Nigerian daily newspapers The Nation, Vanguard, Punch, Sahara Reporters, National Mirror, Premium Times and Tribune are used as sources for deriving data. 


\section{Views on Citizen's Participation}

Democracy is the most common system of government practice in today's world. It is a system of government in which citizens participate in the governance of their country not just by voting in an election but also by monitoring government policies, programs, budgets, and events in the parliament; which will in turn develop their political life and gives them a sense of responsibility. Democracy gives freedoms for citizens to participate in political activities and decision-making processes, which encourages transparency and gives broader citizens participation in development. It is a form of governance in which citizens control public policy and public action by electing persons of their choice to represent them and it is premised on the principles of representation, participation, and accountability (Tandon and Kak 2007). That is, government governs with the consent of the governed; the governed can withdraw their consent and change those in government. Various versions and explanations of democracy attempts to share one fundamental objective that is how to govern society in such a way that power actually belongs to the people (Nabudere 2013). Robert Putman enumerates essential precondition for the success of democracy as active participation of citizens in public affairs, the interaction of citizens as equals and mutual trust and respect among citizens (Cunnigham 2002). Participation of citizen's in public affairs according to Norman Palmer is the involvement of citizens in political activities that directly or indirectly influences the behaviour and actions of decision-makers in the formation of public policy and making them accountable (Pattanaik 2007). Berry stated that increased activity of citizen and advocacy groups would play a significant role in changing ways government policies are formulated (Willis 2008). Aristotle argued that the ultimate goal of human existence is good life and this is possible only through participation within a self-governing community (Oliver 2001). For Myron Weiner citizen participation in governance is a voluntary action, successful or unsuccessful, organized or unorganized, episodic or continuous, employing legitimate or illegitimate methods intended to influence the choice of public policies and political leaders at any level of government (Lane 1997). Participation by the people in the institutions and systems that govern their lives is a basic human right and essential for realignment of political power in favour of disadvantaged groups for social and economic development (Tandon and Kak 2007). Citizen participation in governance is not merely involving in elections or as a voters but as a shapers of government policies and rules which is crucial determinant of effectiveness of governments and a building block of democracy. Citizen should not merely vote during elections and show no further interest in the affairs of the state but they should participate between elections. Participation in the periods between elections is essential to ensure that political representative do not abuse their powers and there is an advancement in the interest of the citizens (Venter 2007). Citizen participation is a given opportunities for citizens to be able to participate in the governmental plan and decision processes. It is important for policy and decision makers to involve citizens with various aspects of developing public policy. Glass James identified the five general objectives of citizen participation as information exchange, education, support building, decision-making supplement, and representational input. According to him, he defined information exchange as bringing planners and citizens together for sharing ideas and concerns. He explained education as an extension of the information exchange objective, which refers to the dissemination of detailed information about a project, about proposed ideas, or about citizen participation itself. He said support building would involve such activities as creating a favourable climate for proposed policies and plans or the resolution of conflict among citizen groups or between citizen groups and the government. For him, the decision-making supplement objective refers to efforts that are designed to provide citizens an increased opportunity for input into the planning process. He further define representative input as an effort to identify the views of the entire community on particular issues in order to create the possibility that subsequent plans will reflect community desires (Glass 1979). In a democratic political system, there is prospects for political development and democratic values, where citizens are free to organize, petition, speak, and demonstrate for or against government and public policies that affect their existence. The United Nations Universal Declaration of Human Rights (Article 19, 20, 21), states that, "Everyone has the right to freedom of opinion and expression...", "Everyone has the right to freedom of peaceful assembly and association", and "everyone has the right to take part in the government of his country, directly or through freely chosen representatives" (United Nations 1948). Similarly Graham et al noted that, "All men and women should have a voice in decision-making, either directly or through legitimate intermediate institutions that represent their intention. Such broad participation is built on freedom of association and speech, as well as capacities to participate constructively". They also states that there should be accountability where decision-makers in government, the private sector, and civil society organizations are accountable, answerable, and responsible to the public, as well as to institutional stakeholders. There should also be transparency which is built on the free flow of information, processes, institutions and information that are directly accessible, sufficient, and applicable to those concerned with them, and enough information is provided to understand and monitor them (Graham et al. 2003). In order for citizens to participate effectively in governance, citizens must be aware of what they want. They must feel that they are socially involved in the whole process of governance. They must be aware of their right 
to participate in political and economic issues. Feeling confident and knowing how and where to participate is a needed criterion. There must be a belief that their participation in decision-making process will yield good result and make a difference, as citizen's input in decision-making progress would generate citizen's oriented policies.

\section{Ensuring Responsibility, Transparency, Accountability and Representation}

In order to ensure proper responsibility, accountability, and representation, when formulating public policy the decision makers need to take into account the interest of the citizens. On the other hand, the citizens are empowered to hold decision makers and elected officers accountable. Citizen's knowledge of politics increases by participating in the process of decision making which will develop their sense of responsibility and that of those representing them.

The five listed events opened an avenue for citizen's participation and significant political change in Nigeria.

First: The prolonged absence of President Yar'Adua from the country on health reasons created a power vacuum. The anxiety over the power vacuum at the executive level of government prompts the public to urge members of national assembly to rise up to their responsibility in saving Nigeria democracy. The long absence of President Yar'Adua from Nigeria between 2009 and 2010 due to health reasons and his refusal to hand over power to his deputy before travelling to Saudi Arabia for medical treatment resulted in a flurry of agitations by Nigerians. A rally tagged 'Enough is Enough' was organized by notable individuals, the public and civil society under the aegis of Save Nigeria Group (SNG); they protested against President Yar'Adua failure to transfer power to the Vice-President Goodluck Jonathan before proceeding on medical treatment in Saudi Arabia. This group said they were protesting four ills of the country. These includes the prolonged absence of the president from the country; vacillation over electoral reforms, corruption, and terror tag on Nigerians (Okolo 2010). They said the rally was meant to prod members of National Assembly out of their docility and to save Nigeria's democracy. On 9th February 2010, the National Assembly in a unanimous resolution voted to transfer power to Vice-President and passed motions that will enable the Vice-President to act as the president in the prolonged absence of the president who was receiving medical treatment in Saudi Arabia (Senate votes to replace President Yar'Adua, Jonathan climbs up, 2010).

Second: On 1st of January 2012, the President of Federal Republic of Nigeria Goodluck Jonathan announced the removal of subsidy from petroleum products as a necessary move to maximize the oil wealth of the country and to save the country from economic crisis as well as to end the vast corruption that had been taking place under the subsidy regime. He said the government is faced with two options with regards to the management of oil sector in the country; either the government deregulate oil sector and survive economically, or continue with a subsidy regime that will continue to undermine the nation's economy and potentials for development (Subsidy protest: Read text of President Jonathan's broadcast, 2012). He said in 2011 alone, fuel subsidy cost the government $\$ 8$ billion and that the expected amount to be higher in the following year. He said the government will inaugurate Subsidy Reinvestment and Empowerment programme (SURE-P) intended to monitor the funds saved from the subsidy and manage their investment in public works projects that may generate 370,000 new jobs, especially jobs for women and youth. (Bid to end subsidy stirs protest in Nigeria: Unrest highlights problems of mismanagement and corruption, 2012) However, in response to the fuel subsidy removal by the federal government, a socio-political protest tagged 'Occupy Nigeria' began across the country. The citizens believed that the federal government had introduced a plan without any regard on how it will affect the cost of living in the country. (What is behind Nigeria fuel protests? 2012) The announcement also drew Nigerians in diaspora to protest against the removal. This removal of subsidy means one hundred percent increase in petroleum products, as well as transportation fares, house rents, school fees, electricity, and food. The protesters across the country said the time has come to end corruption in the oil sector and to hold the public office holders accountable. The protesters listed their demand as follows: the reversal of petroleum products prices and probe into the fuel subsidy scheme and prosecution of individuals found guilty of short-changing Nigeria economy through the subsidy scheme. The protesters demanded accountability in virtually all sectors of government. According to Achike Chude, he said the protest helped in educating Nigerians on the fact that they have a right to question any act of government once they feel that those actions no longer go with their own interests (\#OccupyNigeria: One year later, the gains, the losses, 2013). In response to the demand of the people, the government set up two committees: first, Committee on Verification and Reconciliation of subsidy claims and payments led by Aigboje Aig-Imoukhuede. (Jonathan sets up committee to verify 2011 subsidy claims, 2012) Second, Committee on Petroleum Revenue Task Force led by Mallam Nuhu Ribadu. (FG appoints Ribadu head of petroleum revenue taskforce, 2012) Similarly, the House of Representatives also set up an Ad Hoc Probe Panel on fuel subsidy. In its report, the panel indicted many petroleum marketers and government officials for receiving payment when no petroleum products were imported and supplied (Aig-Imoukhede, chair of presidential panel on subsidy verification, is oil cabal member too, 2012). In a nutshell, the nationwide protest compel the government to reverse its earlier decision 
on fuel subsidy and partially reinstate the subsidy with fuel price set at N97 naira per litre instead of the earlier price at N65 naira per litre.

Third: The interests and desires of Nigerian public were taken into account when the public rose against the building of 'Mission House for African Ladies' in Abuja. In the 2013 budget presented to the National Assembly, the Federal Capital Territory (FCT) allocated the sum of 4billion Naira for the construction of a building for the President's wife. She wanted the building for activities of African first ladies. It was her pet project and a private venture, which she operates under a non-governmental organization. The appropriation of the fund in the FCT budget provoke public outcry (Senate, N4b First Ladies Project, 2013). Various political parties, notable individuals, and civil society groups such as Women Arise for Change Initiative were against the project. Their argument was how concerns of private organization became an item in the budget of FCT and that the allocation is an overwhelming fiscal misappropriation of funds; and that all right thinking members of the society should vehemently resist the project. The protesters also said that the 4billion Naira allocated for the construction of the building could help millions of school age children to receive better education, equip rural clinics with drugs and do the society a host of other good (Soyinka Leads Protest to Fashola over N4bn First Lady House, 2013). Consequently, the National Assembly questioned the 4billion Naira allocated for the first lady's office. They said it would be inappropriate for the government to spend public funds on private venture and that the expenditure would amount to illegality since the Nigerian constitution does not recognize the first lady's office (Senate queries N4bn budget for first lady's project, 2013).

Fourth: The public protested over judgment passed on the senior officer in the police pension board who was involved in the illegal diversion of funds. The judgment demonstrates how Nigerian judiciary that supposes to play a vital role in strengthening Nigeria democracy is constantly engaged in selective enforcement of law and in support of the corrupt elites in the society. The Economic and Financial Crime Commission (EFCC) on 19th February 2012, uncovers a fraud of 32billion Naira in police pension office perpetrated by the senior officials of the commission between 2009 and 2011. The anti-graft agency said that, the officials conspired using a name of a director of pension to draw 13,874 cheques and sequentially withdrew the money from the commission's accounts and shared it among themselves (EFCC uncovers N14bn scam in police pension office, 2012). The EFCC arrested the public officers who were involved in the illegal diversion of funds from police pension. They were taking to court and remanded in the prison pending the determination of their bail application and charges against them. On $28^{\text {th }}$ January 2013 , an Abuja high court convicted and sentenced a former director in the police pension office who has been standing trial for illegally diverting and stealing of funds meant for police pensioners for personal use to six (6) years imprisonment or an option of 750 thousand Naira fine. (Police Pension Fraud: A chronology of plea bargain compromises, 2013). The judgment was delivered after he confessed that he connived with other public officers to steal funds from the commission's account and pleaded guilty to the charges against him. Following the pronouncement of the judgment, a wild protests and public outcry trailed it. The protesters, comprising Anti-Corruption Network (ACN), Association of Unemployed Youths of Nigeria (AUYN), National Association of Nigerian Students (NANS) and other concerned groups, believed that sentence and option of fine passed by the judge is not commensurable with the offence that was committed and that the judgment encourages theft and embezzlement of public funds. The group said, how can we describe a situation where a man that was involved in a fraud could be left off the hook with token amount. That is, 750 thousand Naira option of fine for 32billion Naira theft (Police Pension Fraud: A chronology of plea bargain compromises, 2013). Irk by public condemnation, the House of Representative asked EFCC and Attorney General of the Federation (AGF) to review the judgment (Police Pension Scam: Reps ask EFCC, AGF to appeal judgment, 2013). On 30th of January 2013, the anti-graft agency re-arrested the former Director (Police Pension Scam: EFCC re-arrests Yusufu, Pension Boss, 2013). On 27th of April 2013, the National Judicial Council (NJC) suspends the judge that presides over the police-pension fraud case. The council said that the judge did not exercise his discretion judicially and judiciously with regard to the sentence he passed on one of the accused convicted in the police pension fraud on 28 th January 2013, (NJC suspends Justice Talba over pension fund ruling, 2013).

Fifth: The 255 million Naira BMW armoured cars scandal involving the former Minister of Aviation, Stella Oduah shows how public office holders siphon public funds to satisfy their ostentatious lifestyle at the expense of the masses. In October 2013, the Minister was accused of illegal purchase of armoured cars with public funds for her personal use. She was alleged of conniving with Coscharis Motors Limited and compelling Nigerian Civil Aviation Authority (NCAA) under her ministry to buy her two armoured cars at clearly inflated prices. The purchase of the two armoured cars was neither earmark in the government-approved budget for the agency nor did it comply with the public procurement law of Nigeria (Aviation Minister, Stella Oduah in fresh fake doctorate degree scandal, 2014). In justifying the purchase, the Minister said the purchase of two BMW armoured cars was due to the imminent threats to her life following the bold steps she took to reposition the aviation ministry and as a result, she requested NCAA to purchase the cars for her. The authority of 
NCAA obliged spending the agency's funds to the tune of 255 million Naira to buy the cars (Nigeria's BMW Scandal: Oduah and the Triumph of Corruption, 2013). The purchase of the armoured cars by NCAA for the Aviation Minister at the whooping sum of 255 million Naira sparked a nationwide controversy as many Nigerians and anti-corruption groups were calling for her resignation and prosecution. According to Prof. Itse Sagay, he described the Minister's action as simply wicked and callous. He stated further that the Minister's action is not only outrageous but it is also symptomatic of what is killing this country, and that it is symptomatic of the recklessness of politicians, and public servants who think that public fund and the resources of Nigerians are to be spent totally and completely for their fancy without restraint. (Test case for anti-corruption Battle, 2013) Similarly, the Executive Director of Women Arise for Change Initiative (WACl), Dr. Joe Okei-Odumakin stated that the procurement of the armoured cars showed the level of culture of impunity in the country. She therefore called on the EFCC and other anti-corruption agencies to conduct a holistic investigation into the issue with a view of prosecuting those found culpable in the Aviation Ministry and the NCAA (Bulletproof car scandal: Airline operators, others demand investigation, 2014). Prior to Stella Oduah exit as the Minister of Aviation, the House of Representatives asked its Committee on Aviation to investigate the armoured cars scandal tagged 'Oduahgate'. In their report, the House Committee on Aviation stated, that no budgetary appropriation was in place for the purchase of the armoured cars. In addition, the House Committee said that the president should 'review' the continued engagement of the Minister of Aviation, Stella Oduah for having contravened the Appropriation Act 2013, and the approved, revised thresholds by exceeding the Ministry of Aviation's approval limit of 100 million naira. According to the spokesman for the House of Representatives Mr Zackary Mohammed, he said the word 'review' means a change in status and it's just a mild way of saying that Mr President should sack the Minister (N255m car Scandal: Presidential Panel indicts Oduah, 2014). The controversy surrounding the purchase of the armoured cars culminated in her removal as the Minister of Aviation on the 12 ${ }^{\text {th }}$ of February 2014 (Bulletproof car scandal: At last, EFCC quizzes Stella Oduah, 2014).

It is obvious from the five listed events that there is a need for citizen's participation in governance for effective government policy, transparency, and accountability that will meet the needs and desires of the populace. In order to make government institutions a truly representative of the people and to meet the needs of the masses, citizen participation at all level of governance is indispensable. However, participation of citizens in governance might be indirect in the deliberations, public policy, and decision-making but citizen's involvement in decision making can result in presentation and representations of the public will. When citizens are engage in governance it improves accountability, help governmental bodies and authorities in problem solving. It also creates and increases quality initiatives made by groups and organization. In a situation where the government and decision makers may not take all necessary actions that can help set objectives of realizing a set goal, citizen participation influences government actions. Such actions may be in the context of allocation of natural resources to regions and states, objection to the misappropriation of public fund, reduce corruption and improving public resource management. Citizen participation in governance help in changing the attitudes, beliefs, and behaviours of public office holders. This will in turn help in improving government performance and increase citizen trust.

Sequel to the above, it can be observed that citizen participation does not only mean mobilization of people for or against government polices but a means of conveying information to public office holders and educating the populace; which is an indispensable element of a truly democratic process where people's opinion will be heard and heeded by the decision makers. In order to strengthen democracy and democratic institutions in Nigeria, government and citizens needs to engage each other for better public policies and services. Citizens must be actively involved in the decision making process because their observations and contributions can help provide useful solutions to problems which are part of their daily lives. Involving citizens in the policy development of their country will make government officials and policy makers more accountable for their decisions. Thus, citizen's participation in the local, state, or federal government level is essential for democratic consolidation not simply because it helps citizens aggregate their preferences but it alters their conceptions of themselves and that of their representatives; and in turns, help ensures proper responsibility, accountability, and representation in governance.

\section{Conclusion}

Citizen participation encompasses more than just participating in the electoral processes. Citizen participation is a means where the citizens participate in planning, budget monitoring, and the general decision-making process that directly relates or affects their daily lives. Although, voting in an election is an important moment in citizen's participation, as its outcome can change the political landscape of a country; but is not the only way citizens can participate or get involved in governance. Citizens can play an active role in governance by influencing the decisions of the government on public policies and making elected and public office holders more accountable. Citizen's participation in political activities in a 
young democracy like Nigeria is vitally important as it increases the legitimacy of government policies and enriches the process that helps set the appropriate priorities. Citizen's participation in Nigeria is a valuable element in strengthening its democratic political system. The five listed event indicates that citizen participation in Nigeria, allows government and decision makers to have an understanding of their immediate community needs and as a result, it enhances governmental responsiveness and public acceptance of governmental activities. Citizen participation plays an important role in objecting to the misappropriation of public fund, reducing corruption, and improving public resource management. Obviously, increased citizen's participation in governance remains one of the greatest importance in strengthening democracy and democratic institutions in Nigeria, as democracy without citizen's participation is unimaginable. So, in engendering democratic values and making democratic institutions more responsive to the needs of the masses, full participation by the citizens are needed at all levels of governance, which would enhance the influence of the citizen's and increase political accountability, proper representation and good governance.

\section{References}

Aig-Imoukhede, chair of presidential panel on subsidy verification, is oil cabal member too, Premium Times Newspaper, 2012, http://www.premiumtimesng.com/business/5973-aig-imoukhede_is_oil_cabal_member_too.html

Amechi Okolo, 2010, The State of the American Mind: Stupor and Pathetic Docility Volume II, (Indiana: Xlibris Corporation

Angela V. Willis, 2008, Effective Use of Citizen Participation in Planning Decision-making Processes, Ann Arbor: ProQuest

Anjali Pattanaik, 2007, Women Education, New Delhi: APH Publishing

Annelise Venter, 2007, Municipal Management: Serving the people, Cape Town: Juta and Company Ltd

Eric Ikhilae and Precious Igbonwelundu, "NJC suspends Justice Talba over pension fund ruling" The Nation's Newspaper on April 27, 2013, http://thenationonlineng.net/new/njc-suspends-justice-talba-over-pension-fund-ruling/

Eric Oliver, 2001, Democracy in Suburbia, New Jersey: Princeton University Press

Felix Nwaneri, "Oduahgate: Test case for anti-corruption Battle" National Mirror Newspaper on October 29, 2013, http://nationalmirror online.net/new/oduahgate-test-case-for-anti-corruption-battle/

FG appoints Ribadu head of petroleum revenue taskforce, Vanguard Newspaper on February 07, 2012, http://www.vanguardngr. com/2012/02/fg-appoints-ribadu-head-of-petroleum-revenue-taskforce/

Fidelis Soriwei and Olalekan Adetayo "N255m car Scandal: Presidential Panel indicts Oduah" Punch Newspaper on January 13, 2014, http://www.punchng.com/news/n255m-car-scandal-presidential-panel-indicts-oduah/

Fidelis Soriwei and Nnodim Okechukwu, "Bulletproof car scandal: At last, EFCC quizzes Stella Oduah" Punch Newspaper on April 3, 2014, http://www.punchng.com/news/bulletproof-car-scandal-at-last-efcc-quizzes-stella-oduah/

Frank Cunnigham, 2002, Theories of Democracy: A Critical Introduction, New York: Routledge

Glass J.J, 1979, Citizen participation in planning: the relationship between objectives and techniques, Journal of American planning Association, 45, 2, 180-189

Graham J., Amos, B., and Plumptre, T., 2003, Principles for Good Governance in the 21st Century, Policy Brief 15, Institute on Governance, Ottawa.

Ikechukwu Nnochiri, "Police Pension Scam: EFCC re-arrests Yusufu, Pension Boss" Vanguard Newspaper on January 30, 2013, http://www.vanguardngr.com/2013/01/police-pension-scam-efcc-re-arrests-yusufu-pension-boss/

John Alechenu et.al, "Bulletproof car scandal: Airline operators, others demand investigation" Punch Newspaper on October 18, 2014, http://www.punchng.com/news/bulletproof-car-scandal-airline-operators-others-demand-investigation/

Jonathan sets up committee to verify 2011 subsidy claims, Vanguard Newspaper on July 06, 2012, http://www.vanguardngr.com/ 2012/07/jonathan-sets-up-committee-to-verify-2011-subsidy-claims/

Musikilu Mojeed, "Aviation Minister, Stella Oduah in fresh fake doctorate degree scandal" Premium Times Newspaper on January 8 , 2014, http://www.premiumtimesng.com/news/152958-aviation-minister-stella-oduah-in-fresh-fake-doctorate-degree-scandal.html

Nigeria's BMW Scandal: Oduah and the Triumph of Corruption, Sahara Reporters on October 21, 2013, http://saharareporters.com/ 2013/10/21/nigerias-bmw-scandal-oduah-and-triumph-corruption-punch-newspaper-editorial

Ogala Emmanuel and Ben Ezeamalu, \#OccupyNigeria: One year later, the gains, the losses, Premium Times Newspaper on January 12, 2013, http://www.premiumtimesng.com/news/114890-occupynigeria-one-year-later-the-gains-the-losses.html

Okey Ndiribe and Emman Ovuakporie, "Police Pension Scam: Reps ask EFCC, AGF to appeal judgement" Vanguard Newspaper on January 30, 2013, http://www.vanguardngr.com/2013/01/police-pension-scam-reps-ask-efcc-agf-to-appeal-judgment/

Olasunkanmi Akoni et.al, "Soyinka Leads Protest to Fashola over N4bn First Lady House" Vanguard Newspaper on February 14, 2013, http://www.vanguardngr.com/2013/02/soyinka-leads-protest-to-fashola-over-n4bn-first-lady-house/

Police Pension Fraud: A chronology of plea bargain compromises, Vanguard Newspaper on February 2, 2013, http://www.vanguardngr. com/2013/02/police-pension-fruad-a-chronology-of-plea-bargain-compromises/

Ruth Lane, 1997, Political Science in theory and Practice: The "Politics" Model, New York: M.E. Sharpe

Senate queries N4bn budget for first lady's project, Punch Newspaper on January 31, 2013, http://www.punchng.com/news/senatequeries-n4bn-first-ladys-house/

Senate votes to replace President Yar'Adua, Jonathan climbs up, OsunDefender Newspaper on February 9, 2010, http://www.osun defender.org/?p=7728 
Senate, N4b First Ladies Project, Vanguard Newspaper on June 18, 2013, http://www.vanguardngr.com/2013/06/senate-n4b-first-ladiesproject/

Stephanie Busari, What is behind Nigeria fuel protests? Cable News Network on January 13, 2012 http://edition.cnn.com/2012/01/06/ world/africa/nigeria-fuel-protest-explained/

Subsidy protest: Read text of President Jonathan's broadcast, Vanguard Newspaper on January 07, 2012, http://www.vanguardngr. com/2012/01/subsidy-removal-read-text-of-president-jonathans-broadcast/

Tandon R. and Kak M., 2007, Citizen Participation in democratic governance: In our hands, New Delhi: Concept Publishing Company Tandon R. and Kak M., 2007, Citizen Participation in democratic governance: In our hands, New Delhi: Concept Publishing Company The United Nations. 1948. Universal Declaration of Human Rights (Article 19, 20, 21).

Toyosi Ogunseye, "EFCC uncovers N14bn scam in police pension office" Punch Newspaper on February 19, 2012, http://www.punchng. com/news/efcc-uncovers-n14bn-scam-in-police-pension-office/

Wadada Nabudere, 2013, Peace and Security for African Development: Proceedings of sixth Annual Aisa Young Graduates and Scholars Conference, Pretoria: African Books Collective

Yemisi Akinbobola, Bid to end subsidy stirs protest in Nigeria: Unrest highlights problems of mismanagement and corruption, Africa Renewal on April 2012, http://www.un.org/en/africarenewal//vol26no1/nigeria-subsidy.html 